\title{
Portal and systemic haemodynamic response to acute and chronic administration of low and high dose isosorbide-5-mononitrate in patients with cirrhosis
}

\author{
A L Jones, I H Bangash, J Walker, K J Simpson, N D C Finlayson, P C Hayes
}

\begin{abstract}
Oral isosorbide-5-mononitrate (Is-5-Mn) was given in doses of 10 and $40 \mathrm{mg}$ acutely and chronically (twice daily for four weeks), allowing a nitrate free interval to 25 patients with cirrhosis. Both $10 \mathrm{mg}$ and $40 \mathrm{mg}$ Is-5-Mn reduced the hepatic venous pressure gradient acutely and chronically, without evidence of tolerance. This was achieved by a reduction in the wedged hepatic venous pressure. The effect on mean azygos blood flow was variable with no significant mean change seen acutely or after chronic use with either dose. The variability was dependent not on the dose used but on the initial azygos flow; the flow in patients with initially low values increased and those with high azygos flows decreased after nitrate challenge. The development of the porto-collateral flow seems an important parameter in predicting haemodynamic response to Is-5-Mn.

(Gut 1995; 36: 104-109)
\end{abstract}

Keywords: cirrhosis, isosorbide-5-mononitrate, hepatic venous pressure.

Department of Medicine, Royal Infirmary of Edinburgh A L Jones I H Bangash J Walker K J Simpson N D C Finlayson P C Hayes

Correspondence to: Dr A L Jones, Royal Infirmary, 1 Lauriston Place, Edinburgh EH3 9YW.

Accepted for publication 21 April 1994

Table I Baseline patient characteristics (Values mean (SEM))

\begin{tabular}{|c|c|c|c|}
\hline Variable & $\begin{array}{l}I s-5-M n \\
10 m g(n=12)\end{array}$ & $\begin{array}{l}\text { Is }-5-M n, \\
40 m g(n=13)\end{array}$ & p value \\
\hline Mean age (y) & $\begin{array}{l}59 \cdot 4(3 \cdot 3) \\
42-74\end{array}$ & $\begin{array}{l}56 \cdot 0(2 \cdot 3) \\
40-71\end{array}$ & $\mathrm{p}>0.32$ (NS) \\
\hline $\begin{array}{l}\text { Age range (y) } \\
\operatorname{Sex}(\mathrm{F} / \mathrm{M})\end{array}$ & $\begin{array}{l}42-74 \\
8 / 4\end{array}$ & $\begin{array}{l}40-71 \\
3 / 10\end{array}$ & $\overline{-}$ \\
\hline Aetiology & 10 ALC: 2 PBC & 11 ALC: 1 PBC: 1 SBC & - \\
\hline Child's-Pugh score & $8 \cdot 0(0 \cdot 6)$ & $8 \cdot 1(0 \cdot 6)$ & $\mathrm{p}>0.5$ (NS) \\
\hline Serum bilirubin (umol/l) & $55 \cdot 8(16 \cdot 0)$ & $50 \cdot 4(12.9)$ & $p>0.05$ (NS) \\
\hline Serum albumin $(\mathrm{g} / \mathrm{dl})$ & $34.4(1 \cdot 7)$ & $32 \cdot 2(1 \cdot 7)$ & $p \geqslant 0.5$ (NS) \\
\hline PTR ratio & $1 \cdot 25(0.08)$ & $1.20(0.05)$ & $p \geqslant 0.5$ (NS) \\
\hline $\begin{array}{l}\text { Serum alanine } \\
\text { aminotransferase (U/1) }\end{array}$ & $36 \cdot 2(4 \cdot 9)$ & $32.6(5.9)$ & $\mathrm{p} \geqslant 0.5(\mathrm{NS})$ \\
\hline No with ascites & $7 / 12$ & $9 / 13$ & - \\
\hline
\end{tabular}

PTR=prothrombin ratio; $\mathrm{ALC}=$ alcoholic cirrhosis; $\mathrm{PBC}=$ primary biliary cirrhosis; $\mathrm{SBC}=$ secondary biliary cirrhosis.
Variceal haemorrhage is a major cause of morbidity and mortality in cirrhosis and drug treatment of portal hypertension aims to reduce this. Previous reports show that both isosorbide dinitrate $^{1-12}$ and isosorbide-5-mononitrate (Is-5-Mn $)^{13-17}$ are capable of reducing the hepatic venous pressure gradient or azygos vein (collateral) blood flow, or both, both acutely and with chronic use but the results have been highly variable. For example we, and others, have found that azygos blood flow may increase in some patients in response to nitrate. ${ }^{15-17}$

\section{STUDY PROCEDURE}

Each patient fasted after a light breakfast on the day of the study. Three lead (lead II) ECG monitoring was begun by attachment to a Hewlett Packard HP monitoring system (Germany), and mean arterial blood pressure (manual syphygmomanometer) was checked every five minutes initially until all patients had achieved haemodynamic stability for at least 20 minutes.

A $7.5 \mathrm{~F}$ introducer (Edwards, Critical Care Division, Irvine, USA) was then placed in the right femoral vein under local anaesthesia (10 $\mathrm{ml}$ of $2 \%$ lignocaine). The hepatic venous pressure gradient (wedged hepatic venous pressure minus free hepatic venous pressure) was then estimated by inserting a Sidewinder II catheter (Cordis, USA) into the main hepatic vein under fluoroscopic screening. Inflating and releasing the balloon enabled repeated consistent measurements of wedge and free hepatic pressure respectively to be made. The Hewlett-Packard machine was zeroed for 
Table II Baseline haemodynamic characteristics. (Values, mean (SEM))

\begin{tabular}{|c|c|c|c|}
\hline Variable & $\begin{array}{l}I s-5-M n \\
10 m g(n=12)\end{array}$ & $\begin{array}{l}I s-5-M n \\
40 m g(n=13)\end{array}$ & p value \\
\hline Heart rate $(\mathrm{bpm})$ & $78 \cdot 3(3 \cdot 5)$ & $72 \cdot 5(3 \cdot 0)$ & $\mathrm{p}>0.1(\mathrm{NS})$ \\
\hline $\begin{array}{l}\text { Mean arterial blood pressure } \\
(\mathrm{mm} \mathrm{Hg})\end{array}$ & $93 \cdot 7(4 \cdot 0)$ & $96 \cdot 2(2 \cdot 2)$ & $\mathrm{p}>0.5$ (NS) \\
\hline $\begin{array}{l}\text { Wedged hepatic venous pressure } \\
(\mathrm{mm} \mathrm{Hg})\end{array}$ & $21 \cdot 4(2 \cdot 0)$ & $23 \cdot 2(1 \cdot 6)^{\star}$ & $\mathrm{p}>0.317$ (NS) \\
\hline $\begin{array}{l}\text { Free hepatic venous pressure } \\
(\mathrm{mm} \mathrm{Hg})\end{array}$ & $5 \cdot 5(1 \cdot 2)$ & $7 \cdot 1(1 \cdot 2) \dagger$ & $\mathrm{p}>0.317$ (NS) \\
\hline $\begin{array}{l}\text { Hepatic venous pressure gradient } \\
(\mathrm{mm} \mathrm{Hg})\end{array}$ & $15 \cdot 9(1 \cdot 8)$ & $16 \cdot 4(0 \cdot 7)^{\star}$ & $\mathrm{p}>0.5(\mathrm{NS})$ \\
\hline $\begin{array}{l}\text { Azygos vein blood flow (ml/min) } \\
\text { Liver blood flow ( } \mathrm{ml} / \mathrm{min})\end{array}$ & $\begin{array}{l}378(91) \\
1227(184) \ddagger\end{array}$ & $\begin{array}{c}511(103) \\
1313(159) \uparrow\end{array}$ & $\begin{array}{l}\mathrm{p}>0.317(\mathrm{NS}) \\
\mathrm{p}>0.5(\mathrm{NS})\end{array}$ \\
\hline
\end{tabular}

$\star_{n}=12 ; \nmid n=13 ; \ddagger n=5 ; \wp n=7$.

pressure at the level of the right atrium at the start of each procedure.

Liver blood flow was measured by the constant infusion, indocyanine green dye method. ${ }^{18-19}$ The Sidewinder II catheter was then removed and an azygos catheter was introduced into the azygos vein under fluoroscopic screening. Estimation of the azygos blood flow was made by the thermodilution technique ${ }^{20}$ using $5 \%$ dextrose at $50 \mathrm{ml} / \mathrm{min}$ as injectate. The position of the catheter was noted for the next occasion of its use in that patient to minimise the effect of change of catheter position on flow.

Either a $10 \mathrm{mg}$ or a $40 \mathrm{mg}$ tablet of Is-5-Mn was then administered orally. Heart rate, blood pressure, and azygos vein flow recordings were taken 30 minutes and 60 minutes after administration of the drug. Sixty minutes after administration of the tablet the azygos catheter was removed and the Sidewinder catheter was reinserted into the main right hepatic vein and a further estimation of wedged and free hepatic venous pressure and liver blood flow was made by the above methods.

CHRONIC ADMINISTRATION OF IS-5-MN

Each patient was given 100 tablets of their randomised dose of Is-5-Mn (BoehringerMannheim Ltd) and written instructions to take one tablet at 9 am and one at $5 \mathrm{pm}$ each day - that is, allowing for a nitrate free interval. Each patient was asked to return the box of tablets at the end of the study (for a tablet count). The last morning dose (on the day of

Table III Comparison of the effect of $10 \mathrm{mg}$ and $40 \mathrm{mg} \mathrm{Is}-5-\mathrm{Mn}$ on heart rate, mean arterial blood pressure (MABP), and azygos vein blood $\left(A_{2} B F\right)$ flow in 25 patients with cirrhosis. (Values mean (SEM))

\begin{tabular}{|c|c|c|c|c|c|c|}
\hline Variable & $\begin{array}{l}1 \text { st study } \\
t=0 \mathrm{~min}\end{array}$ & $\begin{array}{l}1 \text { st study } \\
t=30 \\
\min \end{array}$ & $\begin{array}{l}\text { 1st study } \\
t=60 \\
\min \end{array}$ & $\begin{array}{l}\text { After } 1 \\
\text { month } \\
t=0 \\
\text { min }\end{array}$ & $\begin{array}{l}\text { After } 1 \\
\text { month } \\
t=30 \\
\text { min }\end{array}$ & $\begin{array}{l}\text { After } 1 \\
\text { month } \\
t=60 \\
\text { min }\end{array}$ \\
\hline $\begin{array}{l}\text { Dose } \\
\text { Is-5-Mn/no }\end{array}$ & $\begin{array}{l}10 \mathrm{mg} \\
\mathrm{n}=12\end{array}$ & $\begin{array}{l}10 \mathrm{mg} \\
\mathrm{n}=11\end{array}$ & $\begin{array}{l}10 \mathrm{mg} \\
\mathrm{n}=12\end{array}$ & $\begin{array}{l}10 \mathrm{mg} \\
\mathrm{n}=9\end{array}$ & $\begin{array}{l}10 \mathrm{mg} \\
\mathrm{n}=9\end{array}$ & $\begin{array}{l}10 \mathrm{mg} \\
\mathrm{n}=9\end{array}$ \\
\hline $\begin{array}{l}\text { Heart rate } \\
\text { (bpm) }\end{array}$ & $\begin{array}{c}78 \cdot 3 \\
(3 \cdot 5)\end{array}$ & $\begin{array}{c}79 \cdot 0 \\
(3 \cdot 7)\end{array}$ & $\begin{array}{c}80 \cdot 5 \\
(4 \cdot 5)\end{array}$ & $\begin{array}{c}75 \cdot 8 \\
(6 \cdot 1)\end{array}$ & $\begin{array}{c}77 \cdot 3 \\
(6 \cdot 5)\end{array}$ & $\begin{array}{c}77 \cdot 4 \\
(6 \cdot 3)\end{array}$ \\
\hline $\begin{array}{l}\mathrm{MABP} \\
(\mathrm{mm} \mathrm{Hg})\end{array}$ & $\begin{array}{l}93 \cdot 7 \\
(4 \cdot 0)\end{array}$ & $\begin{array}{l}85 \cdot 3^{\star} \\
(4 \cdot 5)\end{array}$ & $\begin{array}{l}88 \cdot 6^{\star} \\
(4 \cdot 5)\end{array}$ & $\begin{array}{l}89 \cdot 6 \\
(4 \cdot 8)\end{array}$ & $\begin{array}{l}87 \cdot 1 \\
(4 \cdot 4)\end{array}$ & $\begin{array}{c}88 \cdot 2 \\
(5 \cdot 2)\end{array}$ \\
\hline$\underset{(\mathrm{ml} / \mathrm{min})}{\mathrm{AzBF}}$ & $\begin{array}{c}378 \cdot 4 \\
(91 \cdot 2)\end{array}$ & $\begin{array}{l}320 \cdot 3^{\star} \\
(91 \cdot 2)\end{array}$ & $\begin{array}{c}324 \cdot 4 \\
(71 \cdot 9)\end{array}$ & $\begin{array}{c}512 \cdot 2 \\
(130 \cdot 0)\end{array}$ & $\begin{array}{c}517 \cdot 2 \\
(152 \cdot 7)\end{array}$ & $\begin{array}{c}664 \cdot 0 \\
(142 \cdot 4)\end{array}$ \\
\hline Dose & $40 \mathrm{mg}$ & $\begin{array}{l}40 \mathrm{mg} \\
\mathrm{n}=13\end{array}$ & $\begin{array}{l}40 \mathrm{mg} \\
\mathrm{n}=13\end{array}$ & $40 \mathrm{mg}$ & $40 \mathrm{mg}$ & $\begin{array}{l}40 \mathrm{mg} \\
\mathrm{n}=11\end{array}$ \\
\hline Heart rate & $72 \cdot 5$ & $83 \cdot 7^{\star}$ & $82 \cdot 7^{\star}$ & $82 \cdot 1^{\star}$ & $87 \cdot 7^{\star}$ & $84 \cdot 0^{\star}$ \\
\hline (bpm) & $(3 \cdot 0)$ & $(3 \cdot 6)$ & $(3 \cdot 6)$ & $(4 \cdot 6)$ & $(5 \cdot 0)$ & $(5 \cdot 7)$ \\
\hline MABP & 96.2 & $87 \cdot 8^{\star}$ & $89 \cdot 2^{\star}$ & $94 \cdot 4$ & $\begin{array}{l}89 \cdot 6 \\
(3.6)\end{array}$ & $\begin{array}{l}90 \cdot 3 \\
(4 \cdot 5)\end{array}$ \\
\hline$(\mathrm{mm} \mathrm{Hg})$ & $(2 \cdot 2)$ & $(2 \cdot 3)$ & $(2 \cdot 0)$ & $(4 \cdot 6)$ & $(3 \cdot 6)$ & $(4 \cdot 5)$ \\
\hline $\begin{array}{l}\text { AzBF } \\
(\mathrm{ml} / \mathrm{min})\end{array}$ & $\begin{array}{l}511 \\
(102 \cdot 6)\end{array}$ & $\begin{array}{l}448 \cdot 5 \\
(104 \cdot 2)\end{array}$ & $\begin{array}{c}445 \cdot 3 \\
(103 \cdot 0)\end{array}$ & $\begin{array}{c}384 \cdot 7 \\
(83 \cdot 1)\end{array}$ & $\begin{array}{c}391 \cdot 0 \\
(100 \cdot 2)\end{array}$ & $\begin{array}{c}491.8 \\
(146.9)\end{array}$ \\
\hline
\end{tabular}

${ }^{\star}$ Denotes significant difference from 1 st study $t=0$ (baseline value) at least at $95 \%$ level. the second invasive procedure) was omitted. The heart rate, blood pressure, hepatic venous pressure gradient, estimated liver blood flow, and azygos vein blood flow were measured again after 28 days of Is-5-Mn treatment both before and after rechallenge with their randomised nitrate dosage using the same methodology as above. Patients were asked to report headaches or any other side effect.

\section{STATISTICAL ANALYSIS}

Results are expressed as mean (SEM) haemodynamic values for each treatment group. Each mean variable at one time point was compared with the haemodynamic value at the time 0 (that is, baseline value) by a two tailed paired Student's $t$ test.

Correlation of changes in each haemodynamic variable with serum albumin, bilirubin, and prothrombin ratio (PTR) was made using the Spearman rank correlation test on Systat Version 5.0 for Microsoft Windows.

\section{Results}

\section{COMPLETION OF THE STUDY}

Twelve patients were randomly allocated to receive $10 \mathrm{mg}$ and 13 to receive $40 \mathrm{mg}$ of Is-5-Mn. Four patients (two in each group) failed to attend for the second invasive procedure and in one patient the procedure was abandoned for technical reasons.

\section{BASELINE HAEMODYNAMIC CHARACTERISTICS}

No significant difference in baseline haemodynamic characteristics between the two treatment groups was seen (Table II).

\section{HEART RATE RESPONSE TO IS-5-MN}

No significant change in heart rate was seen acutely or after four weeks of $10 \mathrm{mg}$ Is-5-Mn twice daily (Table III). In contrast, patients given $40 \mathrm{mg}$ Is-5-Mn showed a significant rise in heart rate 30 and 60 minutes after drug administration which was still present after a month of therapy (Table III).

\section{EFFECT OF IS-5-MN ON MEAN ARTERIAL BLOOD} PRESSURE

Acute administration of either $10 \mathrm{mg}$ or $40 \mathrm{mg}$ Is-5-Mn produced a significant fall in blood pressure after 30 and 60 minutes (Table III). This fall in blood pressure was not sustained up to or after rechallenge with the nitrate at one month (Table III).

EFFECT OF IS-5-MN ON THE HEPATIC VENOUS PRESSURE GRADIENT

Wedged hepatic venous pressure fell significantly 60 minutes after $10 \mathrm{mg}$ Is-5-Mn given initially and after one month of nitrate use (Fig 1). The pressure before challenge at one month, however, was not significantly different from the baseline (first study) value. A dose of 


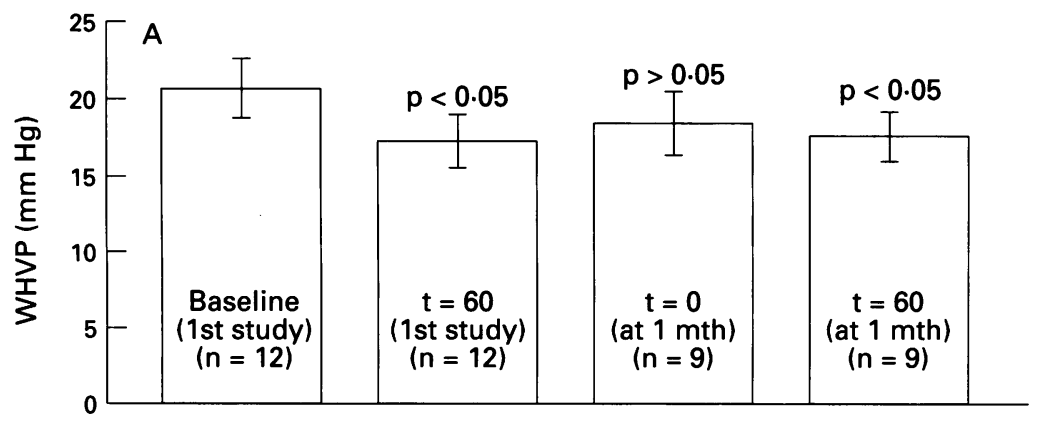

Time (min)
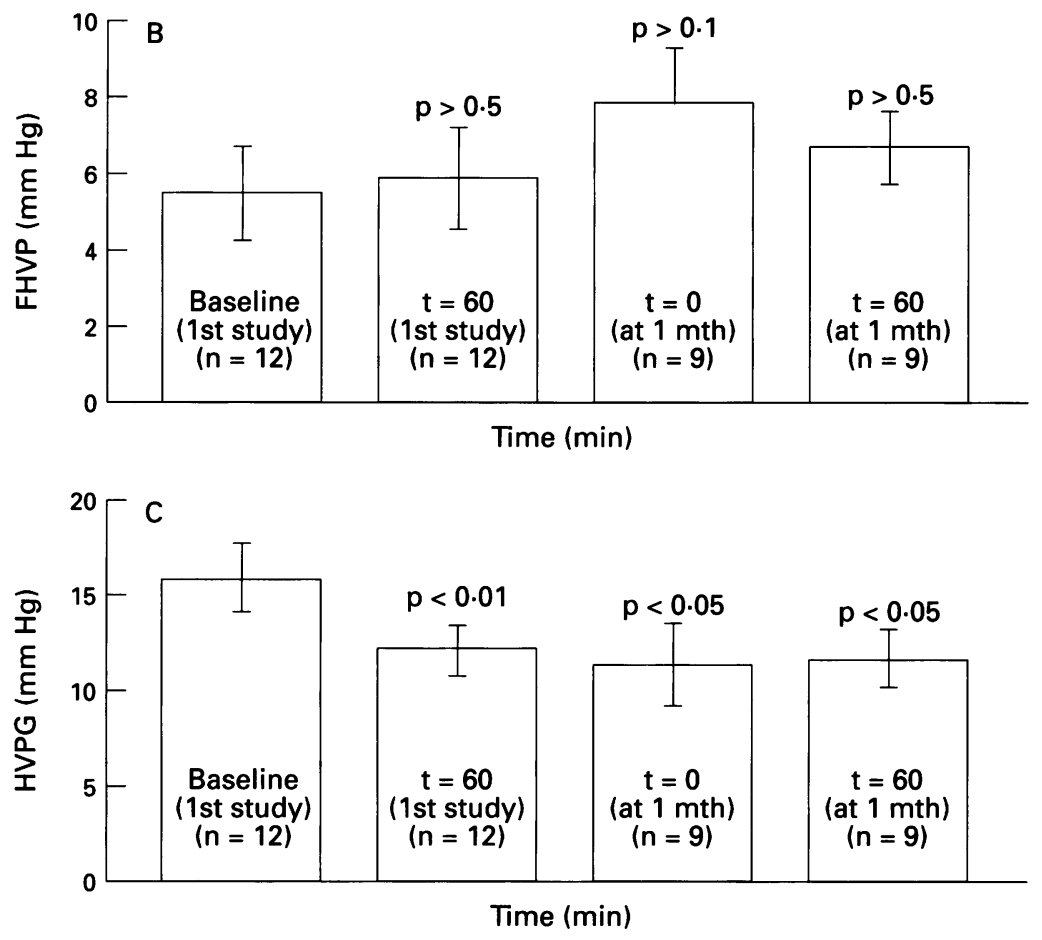

Figure 1: The acute and chronic effect of $10 \mathrm{mg}$ isosorbide-5-mononitrate on mean wedged hepatic venous pressure (WHVP) (A), free hepatic venous pressure (FHVP) (B), and hepatic venous pressure gradient (HVPG) (C) in patients with cirrhosis. Mean values are given and error bars represent standard error of the mean and $p$ values illustrate the result of paired $\mathrm{t}$ testing between values at the time points shown and the baseline $(t=0)$ values.
$10 \mathrm{mg}$ Is-5-Mn had no significant effect on free hepatic venous pressure acutely or after chronic nitrate use (Fig 1). The hepatic venous pressure gradient showed sustained reduction after acute and chronic nitrate use (Fig 1).

The wedged hepatic venous pressure fell significantly acutely and after one month of $40 \mathrm{mg}$ Is-5-Mn (Fig 2), an increasing effect being seen with more exposure to the nitrate. A dose of $40 \mathrm{mg}$ Is-5-Mn had no statistically significant action on the mean free hepatic venous pressure (Fig 2). The hepatic venous pressure gradient showed sustained reduction after acute and chronic nitrate use (Fig 2), the greatest effect being seen on rechallenge with nitrate after a month of treatment.

\section{EFFECT OF IS-5-MN ON AZYGOS VEIN BLOOD FLOW}

A dose of $10 \mathrm{mg}$ Is-5-Mn produced a significant reduction of azygos flow within 30 minutes of administration but thereafter no significant reduction was seen (Table III). Small reductions of azygos flow were seen acutely and chronically after $40 \mathrm{mg}$ Is-5-Mn use but these failed to reach statistical significance (Table III). Most noticeable, however, was the variability of response of azygos blood flow to either dose of the nitrate as illustrated by the large standard error values. This can be explained by division of all 25 patients (that is, both dosage groups) into arbitrary groups at baseline with low (less than $350 \mathrm{ml} / \mathrm{min}$ ), moderate $(350-550 \mathrm{ml} / \mathrm{min})$, and high azygos flows (more than $550 \mathrm{ml} / \mathrm{min}$ ). Although no statistical analysis between the groups would be valid, Figure 3 shows that those with low initial values increase in response to nitrate and those with high initial values reduce in response to nitrate. Those with intermediate values demonstrate little change in response to nitrate.

\section{CORRELATION BETWEEN CHILD'S-PUGH}

VARIABLES AND RESPONSE TO IS-5-MN

(SPEARMAN'S RANK CORRELATION TEST)

No significant correlation was found between the change in heart rate, mean arterial blood pressure, wedged hepatic venous pressure, free hepatic venous pressure, hepatic venous pressure gradient, and azygos blood flow with serum bilirubin, albumin, and prothrombin ratio in response to $10 \mathrm{mg}$ Is-5-Mn at any time point in the first study or at one month.

Similarly, no correlations were found with the $40 \mathrm{mg}$ group of Is-5-Mn except a reduction of free hepatic pressure (in the first hour, first study, $r=-0.72$ ) and reduction of azygos blood flow (in the first hour, second study, $r=0.750)$ were both significantly correlated $(\mathrm{p}<0.05)$ with serum bilirubin. Also, the reduction in wedged hepatic venous pressure at the end of the second study hour (at one month) was correlated with serum albumin $(r=0 \cdot 65)$. Azygos blood flow reduction from baseline to time zero on the first and second study were both correlated with serum albu$\min (r=-0.633$ and --0.667 respectively). Only the reduction in free hepatic venous pressure after the first hour in the first study correlated with the prothrombin ratio $(r=0 \cdot 70)$ in the $40 \mathrm{mg}$ group.

\section{EFFECT OF IS-5-MN ON ESTIMATED LIVER} BLOOD FLOW (ICG METHOD)

Figure 4 shows that only $40 \mathrm{mg}$ Is-5-Mn produces a significant fall in liver blood flow after one hour (which coincides with a drop in the mean arterial blood pressure). The liver blood flow did not show a significant reduction with chronic nitrate use.

\section{SIDE EFFECTS}

Three patients receiving $10 \mathrm{mg}$ Is-5-Mn twice daily reported headaches during the first 24 hours of therapy. One of these patients described persistent headaches over the first two weeks and withdrew from the study.

Five patients reported headaches after starting $40 \mathrm{mg}$ Is-5-Mn which stopped within 24 hours. One of these five patients experienced headaches for 10 days after beginning the tablets, lasting 10-20 minutes after each tablet, and withdrew from the study.

Ten of the $10 \mathrm{mg}$ group of patients $(100 \%$ of 

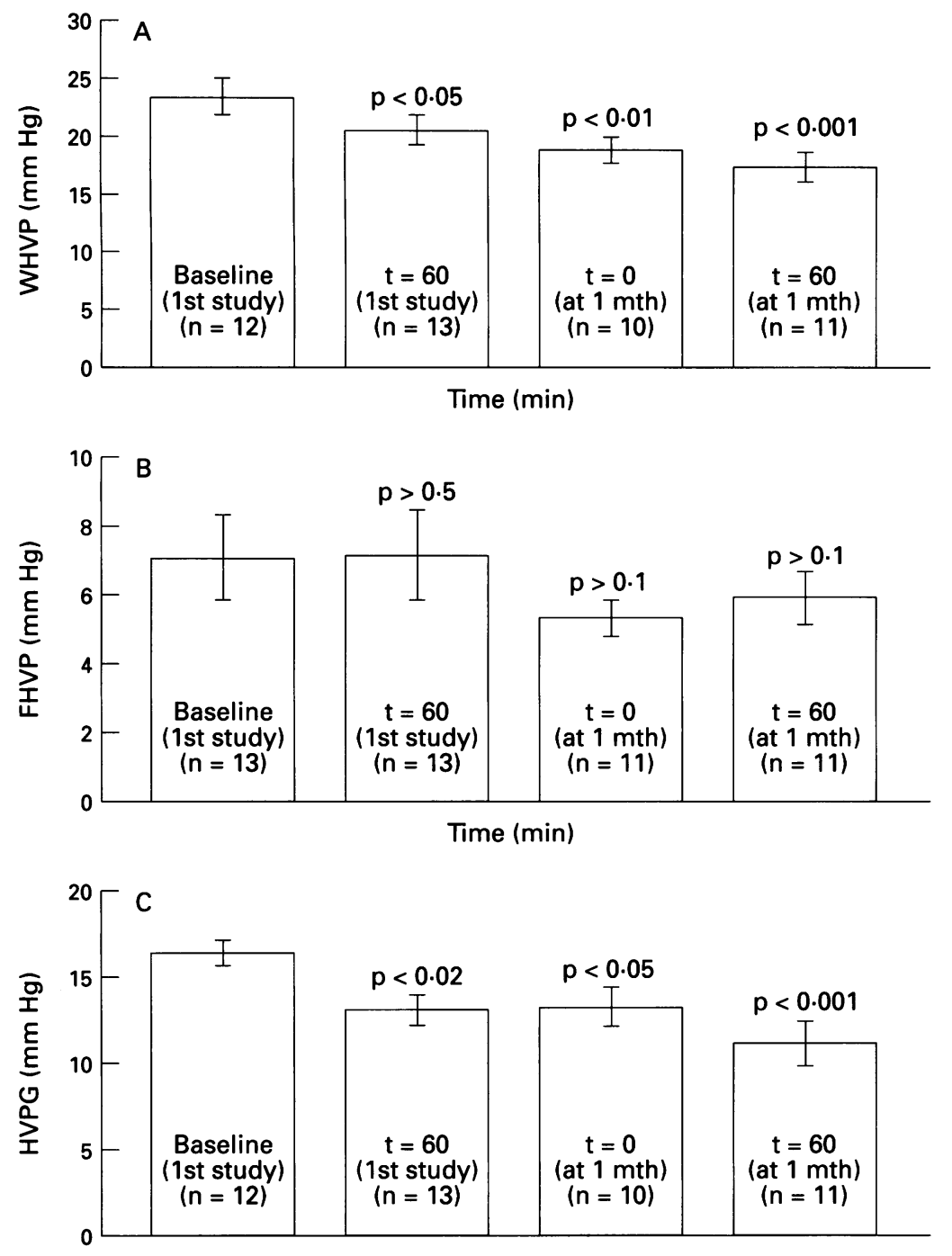

Time $(\mathrm{min})$

Figure 2: The acute and chronic effect of $40 \mathrm{mg}$ isosorbide-5-mononitrate on mean wedged hepatic venous pressure (WHVP) (A), free hepatic venous pressure (FHVP) (B) and hepatic venous pressure gradient (HVPG) $(C)$ in patients with cirrhosis. Mean values are illustrated, error bars represent standard error of the mean and $p$ values illustrate the result of paired $\mathrm{t}$ testing between values at the time points shown and the baseline $(t=0)$ values.
NO EVIDENCE FOR DOSE-DEPENDENCY OF IS-5-MN IN REDUCTION OF HEPATIC VENOUS PRESSURE GRADIENT

Our study suggests that both $10 \mathrm{mg}$ and $40 \mathrm{mg}$ of Is-5-Mn greatly reduce the hepatic venous pressure gradient acutely and with chronic use. This is of clinical relevance given the increasing interest in the use of nitrates to prevent variceal bleeding in cirrhotic patients.

Only two previous groups have shown no effect of nitrates on hepatic venous pressure gradient. ${ }^{214}$ All others showed a reduction in the hepatic venous pressure gradient which was accompanied by a fall in the cardiac index and mean arterial blood pressure (isosorbide dinitrate, ${ }^{1-7}$ Is-5- $\left.\mathrm{Mn}^{13-15}\right)$. In our study there was no apparent advantage of one dose over the other in achieving portal pressure reduction.

HOW IS THE REDUCTION IN HEPATIC VENOUS PRESSURE GRADIENT ACHIEVED?

The reduction of hepatic venous pressure gradient in previous studies and ours (by either dose of Is-5-Mn) was achieved by a fall in the wedged hepatic venous pressure rather than a rise in the free hepatic venous pressure.

Reducing the wedged hepatic venous pressure may be more important than reducing the hepatic venous pressure gradient per se in protection against variceal bleeds. ${ }^{27} 28$

EVIDENCE FOR DIFFERENT DOSES WORKING BY DIFFERENT MECHANISMS

Many haemodynamic studies to date suggest that different doses of nitrate may act by different mechanisms ${ }^{1529}$ and this may well be the case in our study. Certainly, the $40 \mathrm{mg}$ dose seems to induce a greater haemodynamic disturbance acutely - that is, increased heart rate, reduced mean arterial blood pressure, and liver blood flow - than the $10 \mathrm{mg}$ dose. Only the increase in the heart rate effect was maintained after chronic use. Whether this means greater efficacy of the higher dose in prophylaxis of variceal bleeding remains to be evaluated by clinical studies.

ane their un tablets. Nine patients $(90 \%)$ had returned the correct number of tablets and one patient had returned one tablet too many. All claimed to have taken their nitrate tablets diligently and had outpatient appointment attendance rates in excess of $85 \%$.

Nine of the $40 \mathrm{mg}$ group of patients $(81 \cdot 8 \%$ of those attending the follow up haemodynamic study after one month) returned their unused tablets. Eight patients $(72 \cdot 7 \%)$ had returned the correct number of tablets and the remaining patient had three tablets too many. Again all patients claimed to have taken their nitrate tablets and had outpatient appointment attendance rates in excess of $90 \%$.

\section{Discussion}

Is-5-Mn is a powerful venous and mild arterial vasodilator. ${ }^{21}$ It has a prolonged half life (five hours, ${ }^{22}$ little first pass metabolism, ${ }^{23}$ and dose linear kinetics ${ }^{24}$ even in the presence of liver disease. ${ }^{2526}$
HETEROGENEITY IN COLLATERAL VESSEL RESPONSIVENESS TO NITRATES

The efficacy of drugs in controlling an acute rhage may be related to their ability to reduce blood flow through collateral vessels. Determination of the effects of vasoactive agents on both collateral blood flow and the hepatic venous pressure gradient is therefore important in evaluating their therapeutic potential.

Our results indicate that the effect of $10 \mathrm{mg}$ or $40 \mathrm{mg}$ Is-5-Mn on azygos blood flow was highly variable, including some individuals in whom flow increased suggesting vasodilatation of portasystemic collaterals. Those who had a low azygos flow increased their flow in response to nitrate and vice versa. Thus, the degree of pre-existing porta-systemic shunting seems important in the individuals' response to nitrate. variceal bleed or preventing recurrent haemor- 


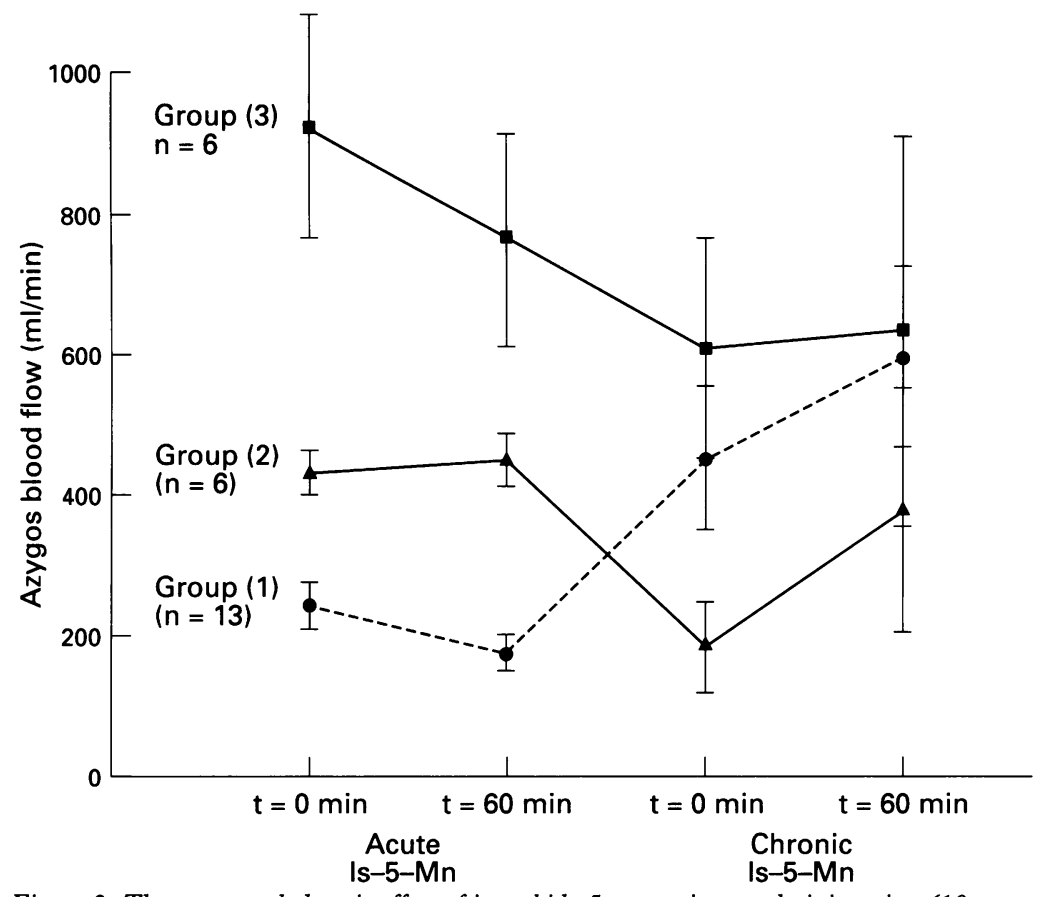

Figure 3: The acute and chronic effect of isosorbide-5-mononitrate administration $110 \mathrm{mg}$ and $40 \mathrm{mg}$ groups combined) on azygos blood flow in patients with cirrhosis. Patients are divided into 3 groups: (1) those with low initial azygos flows ( $<350 \mathrm{~mL} / \mathrm{min}) ;(2)$ those with moderate azygos flows (350-550 $\mathrm{ml} / \mathrm{min}) ;(3)$ those with high azygos flows $(>550 \mathrm{ml} / \mathrm{min})$. Mean azygos flows for each group are shown and the error bars represent standard error of the mean.

ROLE OF SEVERITY OF LIVER DISEASE IN PREDICTING AN INDIVIDUALS' RESPONSE TO NITRATE

The severity of liver disease per se does not seem to be an important variable in defining the haemodynamic response to nitrates as so few haemodynamic changes correlated with serum bilirubin, albumin or prothrombin ratio (which are the best available, though imperfect, measures of severity). A few correla-

Figure 4: The acute and chronic effect of $(A) 10 \mathrm{mg}$ or (B) $40 \mathrm{mg}$ isosorbide-5-mononitrate on liver blood flow (ELBF) estimated by the constant infusion method of indocyanine green. (Mean (SEM) values given. tion tested positively but this would be expected by chance alone given the large number of correlations tested.

Other variables that have previously been suggested to be responsible for different
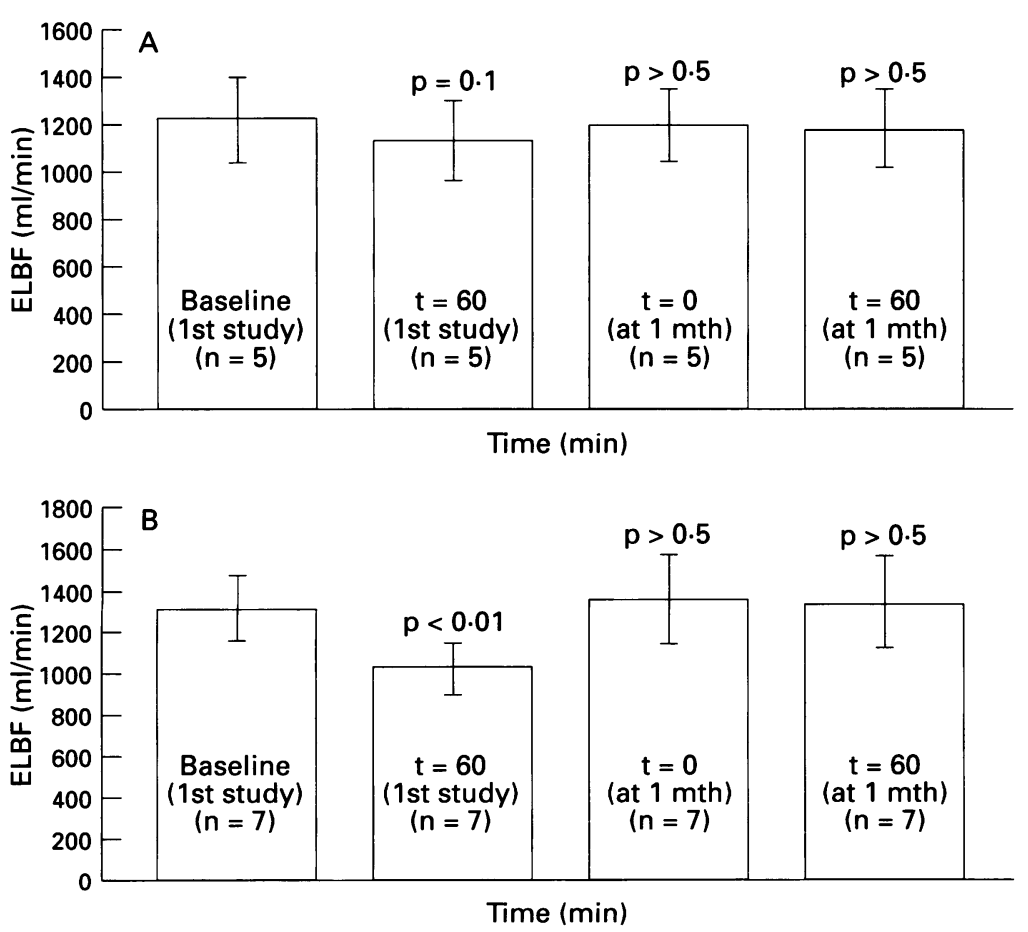

response to nitrates between individuals may be the degree of autonomic impairment ${ }^{30}$ or the baseline cardiac filling pressure. ${ }^{29}$

\section{TOLERANCE TO NITRATES}

Tolerance is well recognised in patients with heart disease given nitrates for 18 hours or longer. ${ }^{31} 32$ Our study and others ${ }^{3}$ 10-12 1416 show a sustained fall in the hepatic venous pressure gradient after chronic nitrate administration, which suggests full tolerance is not of concern in patients with chronic liver disease. To postulate why this may be the case we need to first consider possible mechanisms of tolerance.

Multiple subcellular mechanisms of nitrate tolerance have been postulated, including conversion of the 'nitrate receptor' to the disulphide form with lower affinity for nitrate, ${ }^{33}$ reduction of sulphydryl groups necessary for the 'metabolic activation' of nitrates, ${ }^{34}$ reduction of vascular production of nitric oxide from nitrate, ${ }^{35}$ reduction in vascular metabolism to its dinitrate metabolites, ${ }^{36}$ or molecular alteration of the cellular soluble guanylate cyclase. ${ }^{37}$ These mechanisms explain in vitro phenomena, but are inadequate for the in vivo situation, for example nanomolar concentrations of nitrates cause tolerance in patients versus millimolar concentrations in vitro on blood vessels. ${ }^{38}$

Recent evidence suggests, as expected, that both subcellular and physiological mechanisms are involved in nitrate tolerance in vivo. ${ }^{39}$

Chronic nitrate administration is accompanied by a variety of compensatory physiological effects for example, raised plasma renin, catecholamines, body weight and sodium retention, and shifts in vascular volumes. ${ }^{40-42}$ These findings suggest that in vivo nitrate tolerance might be brought about by physiological compensatory mechanisms.

Patients with cirrhosis have profound physiological disturbance, however, including high plasma catecholamines, sodium retention, and shifts in vascular volumes, ${ }^{43}$ and therefore may not be able to develop further compensatory mechanisms of tolerance.

EFFECT OF NITRATES ON LIVER BLOOD FLOW Calculations of hepatic resistance from previous studies described above and our own study show that either acute or chronic administration of nitrates induce a significant reduction in resistance rather than a reduction in liver blood flow (which would be undesirable). This implies either that portal flow is not reduced or that a compensatory rise in hepatic arterial flow takes place, that is, reciprocity. The difficulty in distinguishing between these two inputs limits or ability to interpret these data further.

\section{COMPLIANCE AND SIDE EFFECTS}

Our data suggest that the patients were taking their nitrate tablets during this study; their motivation to attend outpatient clinics was high and the discrepancy in tablet counts minimal. Side effects were modest. 
CONCLUDING REMARKS

An early clinical trial suggests a prophylactic benefit of nitrates for variceal bleeding, ${ }^{44}$ although larger numbers of patients will be needed in future studies. Our work suggests that chronic administration of either 10 or $40 \mathrm{mg}$ of Is-5-Mn, allowing for a nitrate free interval each day is effective in achieving hepatic venous pressure gradient reduction but there is no non-invasive way of predict collateral vessel response to nitrates.

Nitrates potentially have a number of different mechanisms of hepatic venous pressure reduction which may vary at different doses. Fortunately, by mechanisms which remain to be elucidated, patients with cirrhosis do not develop full tolerance to nitrates.

This work has been presented in part at the British Society of Gastroenterology Annual Meeting 15-17th September 1993 and thus appears in abstract form in Gut 1993; S20: T80.

This work was supported in part by a grant from BoehringerMannheim UK Ltd.

1 Hallemans R, Naeije R, Mols P, Melot C, Reding P Treatment of portal hypertension with isosorbide dinitrate alone and in combination with vasopressin. Crit Care Med 1983; 11: 536-40.

2 Dawson J, Gertsch P, Mosimann F, West R, Elias E. Endoscopic variceal pressure measurements. Response to isosorbide dinitrate. Gut 1985; 26: 843-7.

3 Freeman G, Barton JR, Record CO. Effect of isosorbide dinitrate, verapamil and labetalol on portal pressure in cirrhosis. BMf 1985; 291: 561-2.

4 Merkel C, Finucci G, Zuin R. Effects of isosorbide dinitrate on portal hypertension in alcoholic cirrhosis. $\mathcal{f}$ Hepatol on portal hyperten

5 Blei AT, Garcia-Tsao G, Groszmann RJ. Haemodynamic evaluation of isosorbide dinitrate in alcoholic cirrhosis. Pharmacokinetic-haemodynamic interactions. Gastroenterology 1987; 93: 576-83.

6 Qureshi H, Zuberi S, Faruqui A. Effect of sublingual isosorbide dinitrate on wedged hepatic venous pressure in cirrhotics with portal hypertension. Indian $f$ Gastroenterol 1988; 7: 161-2.

7 Mols P, Hallemans R, Melot C, Lejeune P, Naeije R. Systemic and regional hemodynamic effects of isosorbide Systemic and regional hemodynamic effects of isosorbide
dinitrate in patients with liver cirrhosis and portal hyperdinitrate in patients with liver cirrh

8 Bhatia SJ, Deshmukh H, Abraham P, Shah AV, Voutivillu JA, Jagasia DH, Kothari RH. Effect of sublingua Isosorbide dinitrate on portal hypertension. Indian $\mathscr{f}$ Gastroenterol 1990; 9: 113-5.

9 Merkel C, Bolognesi M, Angeli P, Finucci GF, Amodio P Bellon S, Gatta A. Lack of effect of verapamil and isosorbide dinitrate on the hepatic clearance of indocyanine green in cirrhosis. Br f Clin Pharmacol 1990; 30 (2): 221-7.

10 Cervinka J, Kordac V, Kalab M. Effect of peroral administration of isosorbide dinitrate on portal pressure and blood
flow in patients with cirrhosis of the liver. $\mathcal{f}$ Int Med Res flow in patients with

11 Ikegami M, Toyonaga A, Tanikawa K. Reduction of portal pressure by chronic administration of isosorbide dinitrate in patients with cirrhosis: effects on systemic and splanchnic haemodynamics and liver function. $A m \mathcal{F}$ Gastroenterol 1992; 87: 1160-4.

12 Vorobioff J, Picabea E, Gamen $M$, Villavicencio $R$ Isosorbide dinitrate in portal hypertensive patients. f Hepatol 1992; 16: 387.

13 Hayes PC, Westaby D, Williams R. Effect and mechanism of action of isosorbide-5-mononitrate. Gut 1988; 29: $752-5$.

14 Tsai Y-T, Lee F-Y, Lin H-C, Chang T-T, Lay C-S, Wang $S-S$ et al. Lack of effects of isosorbide-5-mononitrate on $\mathrm{S}-\mathrm{S}$ et al. Lack of effects of isosorbide-5-mononitrate on
hepatic haemodynamics in $\mathrm{HBsAg}$-positive cirrhosis. hepatic haemodynamics $1989 ; 10: 283-7$.

15 Navasa M, Chesta J, Bosch J, Rodes J. Reduction of portal pressure by isosorbide-5-mononitrate in patients with cirrhosis. Gastroenterology 1989; 96: 1110-18.

16 Garcia-Pagan JC, Feu F, Nevasa M. Long-term haemodynamic effects of isosorbide-5-mononitrate in patients with cirrhosis and portal hypertension. $\mathcal{F}$ Hepatol 1990; 11 189-95.

17 Grose RD, Plevris JN, Redhead DN, Bouchier IAD, Hayes PC. The acute and chronic effects of isosorbide-5-mono-
nitrate on portal haemodynamics in cirrhosis. $\mathcal{F}$ Hepatol 1994; 20 (4): 542-7.

18 Cherrick GR, Stein SW, Leevy CM, Davidson CS. Indocyanine green: observations on its physical properties, plasma decay and hepatic extraction. $\mathcal{f}$ Clin Invest 1960; 39: $592-600$.
19 Winkler K, Larsen JA, Munkner T. Determination of the hepatic blood flow in man by simultaneous use of five test substances measured in two parts of the liver. Scand $\mathcal{F}$ Clin Lab Invest 1965; 17: 423-32.

20 Hayes PC, Terrace D, Peaston I, Bouchier IAD, Redhead D, Brash HM. Computerised system for the continuous measurement of azygos venous blood flow. Gut 1992; 33 372-4.

21 Bogaert MG, Rosseel MT. Vascular effects of dinitrate and mononitrate esters of isosorbide, isomannide and isoiodide. Naunyn Schmiedberg's Arch Pharm 1972; 275: 339-47.

22 Taylor T, Chasseaud LF, Major R, Doyle E. Isosorbide-5mononitrate pharmacokinetics in humans. Biopharm Drug Dispos 1981; 2: 255-63.

23 Abshagen U, Betzien G, Endele R, Kaufmann B. Pharmacokinetics of intravenous and oral isosharbide-5-mononitrate. Eur $\mathcal{f}$ Clin Pharmacol 1981; 20:
s. sorbide- $269-75$.

24 Abshagen U. Overview of pharmacokinetics of Is-5-Mn. In: Abstracts of the second international symposium on mononitrates. Berling: Boehringer Mannheim, 1986.

25 Steudel HC, Volkenandt M, Steudel AT. Pharmacokinetics of isosorbide-5-mononitrate after oral and intravenous administration in patients with liver cirrhosis. $Z$ Kardio 1983; 72 (Suppl): 24-8

26 Akpan W, Endele R, Neugebauer G, Steudel H. Pharmacokinetics of Is-5-Mn after oral and intravenous administration in patients with hepatic failure. In: Cohn JR, Rittinghausen R, eds. Mononitrates. Berlin, Heidelberg; Springer-Verlag, 1985; 86-91.

27 Bosch J. Effect of pharmacological agents on portal hypertension; a haemodynamic appraisal. Clin Gastroenterol $1985 ; 14: 169-84$.

28 Bosch J, Bordas JM, Mastai R. Effects of vasopressin on the intravariceal pressure in patients with cirrhosis: comparison with the effects on portal pressure. Hepatology 1988; 8: 861-5.

29 Rector WG, Hossack KF, Ready JB. Nitroglycerin for portal hypertension - a controlled comparison of the haemodynamic effects of graded doses. $\mathcal{F}$ Hepatology 1990; 10: 375-80.

30 Moreau R, Roulot D, Braillon A. Low dose nitroglycerin failed to improve splanchnic haemodynamics in patients with cirrhosis: evidence for an impaired cardiopulmonary with cirrhosis: evidence for an impaired cardiopulex function. Hepatology 1989; 10: 93-7.

31 Elkayam U, Kulick D, McIntosh N. Incidence of early tolerance to haemodynamic effects of continuous infusion of nitroglycerin in patients with coronary artery disease and heart failure. Circulation 1987; 76: 577-84.

32 Jugdutt BI, Warnica W. Tolerance with low dose intravenous nitroglycerin therapy in acute myocardial infarction. Am f Cardiol 1989; 64: 581-7.

33 Fung H-L, Chong S, Kowaluk E. Mechanisms of nitrate action and vascular tolerance. Eur Heart f 1989; 10 (suppl A): $2-6$.

34 Ignarro LJ, Lippton H, Edwards JC, Baricos WH, Hyman AL, Kadowitz PJ, Gruetter CA. Mechanism of vascular smooth muscle relaxation by organic nitrates, nitrites, smooth muscle relaxation by organic nitrates, nitrites,
nitroprusside and nitric oxide; evidence for the involvenitroprusside and nitric oxide; evidence for the involvement of

35 Chung S-J, Fung H-L. Relationship between nitroglycerininduced vascular relaxation and nitric oxide production probes with inhibitors and tolerance development. Biochem Pharmacol 1993; 45: 157-63.

36 Slack CJ, McLaughlin BE, Brien JF, Marks GS, Nakatsu K Biotransformation of glyceryltrinitrate and isosorbide dinitrate in vascular smooth muscle made tolerant to organic nitrates. Can $\mathcal{f}$ Physiol Pharmacol 1989; 67: organic

37 Waldman SA, Rapoport RM, Ginsburg R, Murad F. Desensitization to nitroglycerin in vascular smooth muscle Desensitization to nitroglycerin in vascular smooth muscle from rat

38 Fung $\mathrm{H}-\mathrm{L}$. Pharmacokinetics of nitroglycerin and long acting nitrate esters. $A m \mathcal{F}$ Med 1983; 74 (suppl 6B): 13-20

39 Watanabe H, Kakihana M, Ohtsuka S, Enomoto T, Yasui K, Sugishita Y. Platelet cGMP - a potentially useful indicator to evaluate the effects of nitroglycerin and nitrate tolerance. Circulation 1993; 88: 29-36.

40 Packer M, Lee WH, Kessler PD, Gottlieb SS, Medina N, Yushak M. Prevention and reversal of nitrate tolerance in patients with congestive heart failure. N Engl f Med 1987; 317: 799-804.

41 Dupuis J, Lalonde G, Lemieux R, Rouleau JL. Tolerance to intravenous nitroglycerin in patients with congestive heart failure: role of increased intravascular volume, neurohumoral activation and lack of prevention with $\mathrm{N}$-acetylcysteine. F Am Coll Cardiol 1990; 16: 923-31

42 Parker JD, Farell T, Cohanim M, Parker JO. Counterregulatory responses to continuous and intermitten therapy with nitroglycerin. Circulation 1991; 84: 2336-45.

43 Sherlock S, Dooley J. Diseases of the liver and biliary system. Oxford: Blackwell Scientific Publications, 1993.

44 Angelico M, Carli L, Piat C, Gentile S, Rinaldi V, Bologna E, Capocaccia L. Isosorbide-5-mononitrate versus propranolol in the prevention of first bleeding in cirrhosis. Gastroenterology 1993; 104: 1460-65. 